\title{
Leger er vennlige, men ikke interesserte
}

\section{Leger viser ofte liten interesse \\ for pasientenes personlige bekym- ringer. Trass i en ellers høflig oppførsel kan dette oppleves som krenkende.}

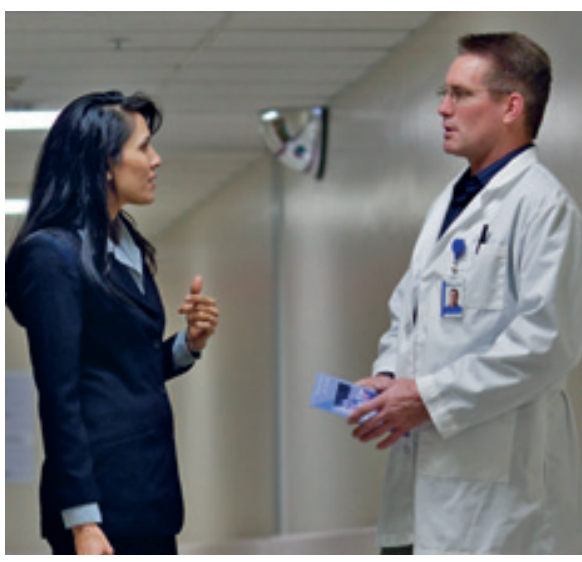

Illustrasjonsfoto Istockphoto
Å ivareta pasienten er tradisjonelt blitt ansett som en viktig del av legegjerningen, og økt vektlegging av kommunikasjon og etikk i medisinstudiet de siste tiårene synes å understreke dette idealet. Men hvordan ivaretar legene sine pasienter i praksis? Vi har nå undersøkt dette ved å observere videoopptak av pasientkonsultasjoner i sykehus (1).

Resultatene viste at pasientene ble godt ivaretatt medisinsk sett, men at deres personlige bekymringer ble systematisk oversett. Samtidig som de fleste legene var vennlige, høflige og holdt en god tone under konsultasjonen, ledet de aktivt samtalen vekk fra pasientenes mer eksistensielle bekymringer og konsentrerte seg om medisinske fakta. Legene tok sjelden opp personlige eller følelsesmessige sider ved pasientens tilstand, selv ikke ved alvorlige og kroniske lidelser, og avviste pasientenes forsøk på å tilnærme seg eksistensielle spørsmål.

Den sterke medisinske vektleggingen gjorde at legene ofte forholdt seg til pasien- tene mer som medisinske objekter enn som medmennesker. $\AA$ bli avvist og behandlet som objekt innebærer imidlertid et moralsk overtramp som av pasienten kan oppleves som krenkende, noe flere av konsultasjonene tydet på. Det virket imidlertid som om legene, fordi de samtidig var vennlige, ikke oppfattet at de begikk noe overtramp. Studien indikerer at slike moralske krenkelser til en viss grad er uunngåelig i klinisk arbeid, men at legene bør være klar over ubehaget de påfører pasientene og hvordan de kan minske det.

\section{Kari Milch Agledahl}

kari.agledahl@helse-finnmark.no

Helse Finnmark

Hammerfest

\section{Litteratur}

1. Agledahl KM, Gulbrandsen P. Førde R et al. Courteous but not curious: how doctors' politeness masks their existential neglect. A qualitative study of video-recorded patient consultations. J Med Ethics 2011; e-publisert 24.5.

\section{Mye TV-titting - øt sykelighet og dødelighet}

\section{Åtilbringe mye tid foran fjernsynet er assosiert med økt risiko for både type 2-diabetes, kardiovaskulær sykdom og død. Dette viser en meta- analyse publisert i JAMA.}

TV-titting er, nest etter arbeid og søvn, den aller vanligste daglige aktiviteten for store deler av befolkningen. Den gjennomsnittlige europeer tilbringer om lag $40 \%$ av sin fritid foran fjernsynet (1). Lite er imidlertid kjent om helseeffektene av dette.

Metaanalysen omfattet åtte store prospektive kohortstudier (2). Analysene viste at relativ risiko per to timer daglig TV-titting var 1,20 for type 2-diabetes, 1,15 for fatal og ikke-fatal hjerte- og karsykdom og 1,13 for totaldødelighet. Mens sammenhengen mellom antall timer daglig TV-titting og risikoen for diabetes og hjerte- og karsykdom var lineær, økte totaldødeligheten først etter mer enn tre timers daglig TV-titting.

- Denne metaanalysen bekrefter at mange timer foran TV-skjermen har en klar assosiasjon til utvikling av type 2-diabetes, hjerte- og karsykdom og totaldødelighet, sier avdelingsoverlege Tor Ole Klemsdal ved Avdeling for forebyggende medisin, Oslo universitetssykehus, Ullevål.
- I en tid hvor stadig mer av både fritid og arbeidstid brukes foran dataskjermen, er det likevel fortsatt usikkert hvorvidt skjermtid i seg selv bør oppfattes som skadelig eller om den negative effekten skyldes assosiert atferd knyttet til matinntak og redusert fysisk aktivitet. Andre faktorer, f.eks. sosioøkonomisk status, kan også spille inn, sier Klemsdal.

\section{Are Brean}

are.brean@legeforeningen.no

Tidsskriftet

\section{Litteratur}

. Office for Official Publications of the European Communities. Time use at different stages of life: results from 13 European countries, July 2003. http://epp.eurostat.ec.europa.eu/cache/ ITY_OFFPUB/KS-CC-03-001/EN/KS-CC-03-001EN.PDF (6.7.2011).

2. Grøntvedt A, Hu FB. Television viewing and risk of type 2 diabetes, cardiovascular disease, and allcause mortality: a meta-analysis. JAMA 2011; 305 $2448-55$.

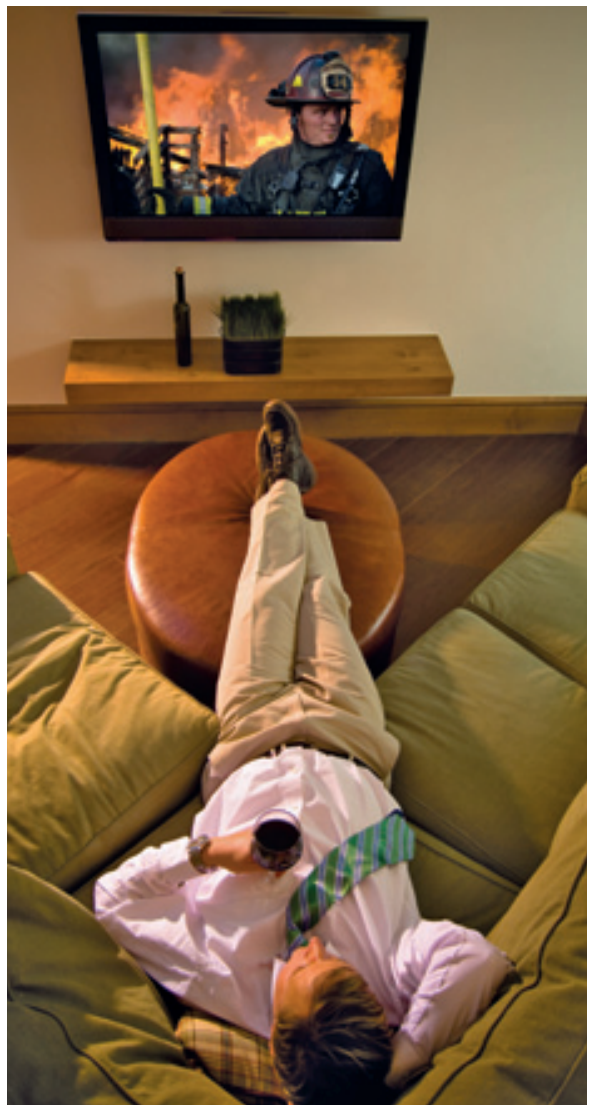

Illustrasjonsfoto Istockphoto 